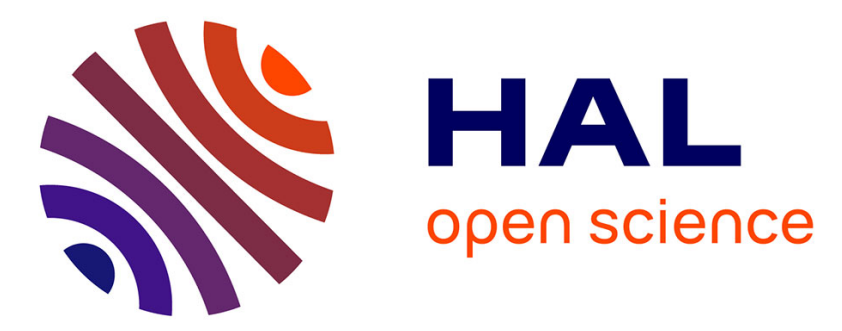

\title{
The eutrophication process of Nador's lagoon (Morocco) evaluated by the Life Cycle Impact Assessment method
}

Gaétana Quaranta, Mohammed Karim Bloundi, Norbert Clauer, Joelle

Duplay

\section{- To cite this version:}

Gaétana Quaranta, Mohammed Karim Bloundi, Norbert Clauer, Joelle Duplay. The eutrophication process of Nador's lagoon (Morocco) evaluated by the Life Cycle Impact Assessment method. Arabian Journal of Geosciences, 2021, 14 (5), 10.1007/s12517-021-06685-4 . hal-03360543

\section{HAL Id: hal-03360543 \\ https://hal.science/hal-03360543}

Submitted on 4 Oct 2021

HAL is a multi-disciplinary open access archive for the deposit and dissemination of scientific research documents, whether they are published or not. The documents may come from teaching and research institutions in France or abroad, or from public or private research centers.
L'archive ouverte pluridisciplinaire HAL, est destinée au dépôt et à la diffusion de documents scientifiques de niveau recherche, publiés ou non, émanant des établissements d'enseignement et de recherche français ou étrangers, des laboratoires publics ou privés. 


\title{
The eutrophication process of Nador's lagoon (Morocco) evaluated by the Life Cycle Impact Assessment method
}

\author{
Gaétana Quaranta ${ }^{1}$ \& Mohammed Karim Bloundi ${ }^{2}$ \& Joëlle Duplay ${ }^{3}$ \& Norbert Clauer ${ }^{4}$
}

Received: 1 July 2020 / Accepted: 3 February 2021

\#Saudi Society for Geosciences 2021

\begin{abstract}
The Nador lagoon system of northeastern Morocco represents the largest regional paralic hydro-system between the Mediterranean Sea and the African continent. Due to its importance, this lagoon is one of the five Sites of Biological and Ecological Interest (SIBE) and was classified in 2005 as a protected site by the international Ramsar treatise. The Nador lagoon is subjected to eutrophic impacts due to pollutant releases from a wastewater plant, three major cities, an agricultural site, and to varied inputs carried by rivers draining the lagoon watershed. The $\mathrm{NQ}^{-}, \mathrm{NQ} ; \mathrm{NH}_{4}^{+}$, and $\mathrm{PQ}^{3-}$ contents of nine water samples collected during summer and winter times at different places in the lagoon were measured and translated in terms of the Redfield ratio (N/P) and the Aquatic Eutrophication Potential. The analyses show that N/P is less than 16 in terms of the Redfield ratio, which designates $\mathrm{N}$ as the limiting factor for the algal growth over the entire lagoon. However, one of the higher N/P ratios was obtained next to the releases of the Beni-Ensar city and near the outlets of the wastewater plant and the nearby Bouaroug creek. The aquatic eutrophication potential of the phosphorus compounds (AEP (P)) is systematically greater than the aquatic eutrophication potential of the nitrogen compounds $(\mathrm{AEP}(\mathrm{N}))$, whether in winter or summer, which confirms that nitrogen is the limiting factor for the local algal growth.
\end{abstract}

Keywords Eutrophication · Nitrogen · Phosphorus · Nador lagoon · Life Cycle Impact Assessment

\section{Introduction}

Coastal environments around the Mediterranean Sea are subjected to increasing impacts that result from concomitant urban, industrial, and touristic developments. These impacts induce potential pollution and degradation, and therefore

Responsible Editor: Amjad Kallel

* Gaétana Quaranta quaranta@unistra.fr

1 Institut Pluridisciplinaire Hubert Curien, Université de Strasbourg, 23 rue du Loess, 67037 Strasbourg-Cedex, France

2 RSK BENELUX, Chaussée de Namur 119, 1400 Nivelles, Belgium

${ }^{3}$ Ecole et Observatoire des Sciences de la Terre, Laboratoire d'Hydrologie et de Géochimie de Strasbourg, Université de Strasbourg, 1 rue Blessig, 67084 Strasbourg-Cedex, France

${ }^{4}$ Ecole et Observatoire des Sciences de la Terre, Institut de Physique du Globe de Strasbourg, Université de Strasbourg, 5 rue Descartes, 67000 Strasbourg, France concerns about the sustainable development. This new situation means also that more thoughts have to be given to sustainableenvironmental aspects including the protection of natural resources, the reduction of pollutant emissions, and the preservation of the fauna and the flora. Among all lagoons exposed to various sources of pollution along the southern shelf of the Mediterranean Sea, that of Nador has been examined in detail during a period of more than 10 years from 1982 to 1993 (Maanan et al., 2015; Lefebvre et al. 1997). For instance, eutrophication increased significantly with a significantly higher supply of organic matter and sediments over time, with a concomitant proliferation of algae called "harmful algal blooms" (Lapointe et al., 2015; Ruiz et al., 2006).

Examination of this algal proliferation has been used to eval- 45 uate the sanity of different lagoons (Benchekroun et al., 2013; 46 Dokulil, 2003; Hédouin et al., 2008). As the global confine- 47 ment of the Nador lagoon increased also slightly, this initial 48 information incited us to examine again the varied inputs of 49 the potential pollutants into the lagoon. As the Life Cycle 50 Impact Assessment (LCIA) applied to evaluate lagoon eco- 51 systems by measuring the nutritive elemental concentrations 52 of another lagoon system has raised interesting applicable 53 
conclusions (Hadj et al. 2008), this method was used again in the frame of this study.

\section{Setting of the lagoon anddescription of the studied materials}

The lagoon of Nador is located on the eastern Mediterranean coast of Morocco $\left(35^{\circ} 10 \mathrm{~N}, 2^{\circ} 55\right.$ to $2^{\circ} 45 \mathrm{~W}$ ) near the Algerian border (Fig. 1). It is bound to the NW by the Cap des Trois Fourches and to the SE by the Cap de l'Eau. Of limited size with a surface of $115 \mathrm{~km}^{2}(25$ by $7.5 \mathrm{~km})$ with a depth never exceeding $8 \mathrm{~m}$, it is open to the sea by a pass (Fig. 1b). Three agglomerations, namely Beni Ensar, Nador, and Arekman Village from NW to SE, as well as a wastewater plant and an ore treatment plant are located around the lagoon, which is also used as a fish breeding place. The lagoon has clearly a social and economic impact for the whole region and has a major local socio-economic and ecological interest (Giuliani et al., 2015; Orbi et al., 2008).

At each end of the lagoon, creeks (called oueds) carry temporarily used surficial waters, which explains why any physical or chemical modification of the lagoon ecosystem may have a significant impact, reducing or even stopping the fish 74 production and consequently causing unemployment. In fact, 75 modifying the environment of the lagoon is also an identified 76 risk due, for instance, to the construction of jetties that can 77 potentially silt up the coast and therefore plug the pass to the 78 sea. A progressive closing of the lagoon will potentially in- 79 crease the salinity of the water due to an increased evaporation 80 relative to a lowering of the water supply. The implication for 81 the Nador lagoon would be an increased organic and inorganic 82 contamination due to increasing urban releases generated by a 83 continuously increasing local and touristic population.

\section{The Nador ecosystem}

Studies in geomorphology, sedimentology, and geochemistry were carried out on the ecosystem of Nador lagoon, which helps to understand better how it functions (Tesson and Gensous 1981; Guelorget and Perthuisot 1983; Inani 1995; Elalami et al. 1998; Mahjoubi 2001; Irzi 2002; Mahjoubi et al. 2003; Bloundi 2005). Also called Bou Areg Sebkha, the Nador lagoon can be divided into three physiographic domains (Fig. 1): the continental border, the lagoon itself, and the barrier island. The continental border includes salt

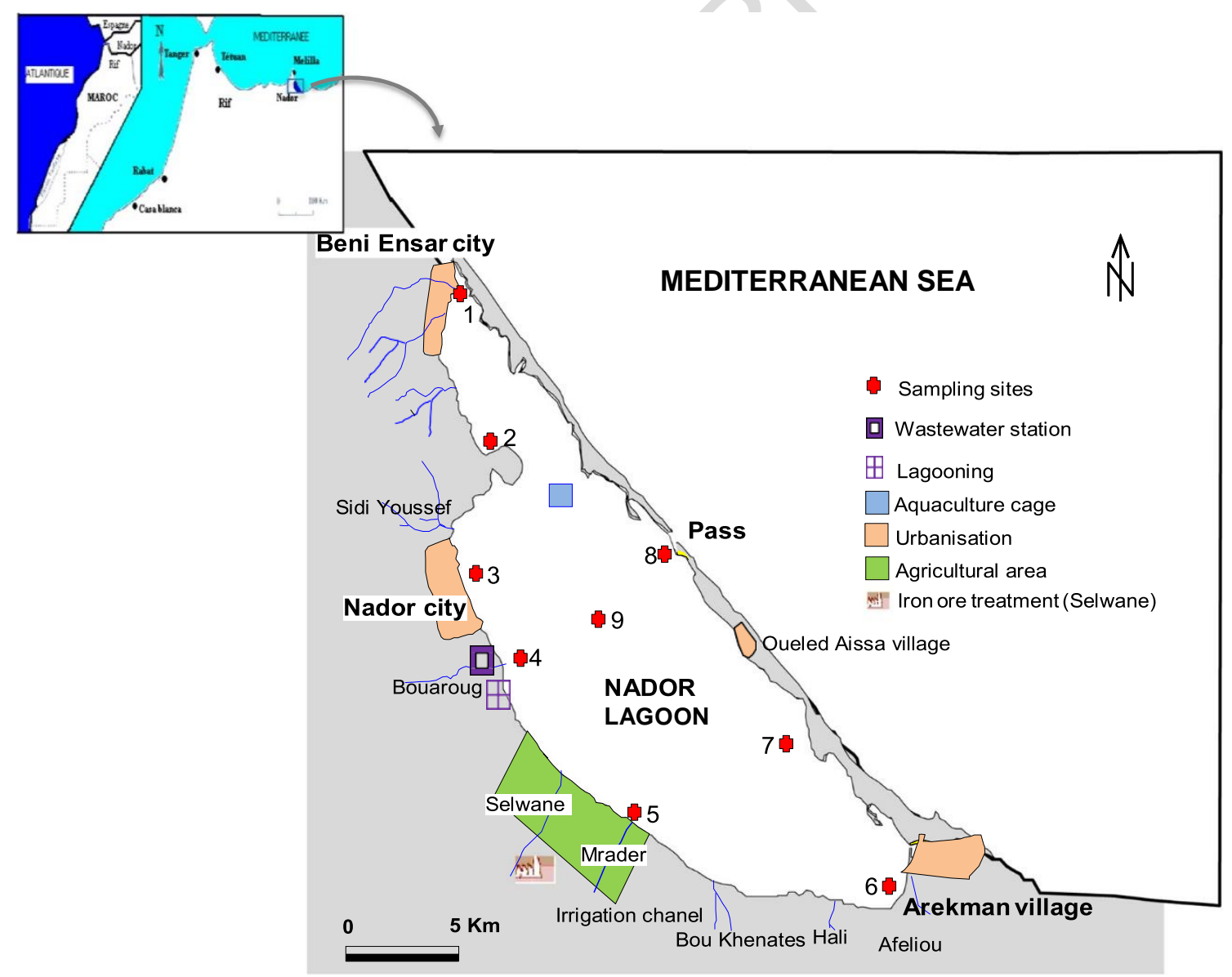

Fig. 1 Locations of the water sampling places and of the main anthropogenic supplies around the Nador lagoon 
marshes and oued outlets, the most important being oued Selwane. The barrier island oriented NW-SE is about $25 \mathrm{~km}$ long and has an average width of 300-400 m, becoming $2 \mathrm{~km}$ wide at its southeastern end, and containing an artificial pass called Bokhana. The lagoon itself is fed not only by natural oueds that have torrential flows from time to time but also by several man-constructed outlets such as irrigation channels and urban releases. Two water supplies by the Bou Areg and Gareb oueds are in contact with the lagoon waters, which are also infiltrated by salt waters from sea waves breaking on the barrier island and by seawater flows into the inlet.

The human anthropogenic activities around the Nador lagoon are diverse. They induce varied types of releases: (1) developing infrastructures that include land transport and traffic, and recreational facilities that produce waste waters, municipal waste, and fuels; (2) the nearby airport activity; (3) local industrial activities including active and abandoned mining, excavation sites, industrial plants and storage sites, treatment of waste waters, harbour, and port facilities; and (4) livestock, agriculture, aquaculture, and fisheries. The main vectors of the pollution issued from these activities are the oueds, which waters are used often as discharges of up-stream built-up sewers by irrigation canals, treated urban discharges of the city of Nador to the south, nontreated releases from Arekman Village to the southeast, from the city of Beni Ensar to the northwest, and streaming waters (Bloundi et al. 2008a). The amount of fresh water drained into the lagoon was estimated to average about $19,000 \mathrm{~m}^{3} /$ year, but this contribution is decreasing since the construction of a dam upstream the oued Selwane.

Mabrouk (1988) showed that untreated wastewaters induce bacteriological contamination around the releasing zones. In fact, the only facility for domestic waste collection around the lagoon is located near the city of Nador. It is dedicated to the downtown population and that of some suburban districts. It cleans only $70 \%$ of the city domestic waters, the remaining $30 \%$ being evacuated into individual wells. Treating about $10,000 \mathrm{~m}^{3}$ of water per day that are subjected to biological treatments, the nearby wastewater station is based on the principle of the activated sludge. Although visible, the pollution decrease may not be effective enough because of varied systematic failures in the physical, chemical, or micro-biological controls of the treated waters, lacking of the necessarily periodic disinfection operations of the treatment equipment, as well as cuts of the electrical power and defects of the electro-mechanical system, which altogether alter the quality, and also the reliability of the water treatment. Other towns and villages around the lagoon, such as Beni Ensar and Arkmane Village, evacuate directly their faecal waters into the lagoon without any treatment.

\section{The lagoon eutrophication}

Eutrophication is presently a major form of controlling the water pollution that affects aquatic ecosystems around the world. It is a natural process by which waters become excessively enriched in nutrients, such as nitrogen and phosphorus. It is a way along which water bodies, such as lakes, rivers, and seas, change because their nutrients become progressively enriched, from scarce (oligotrophic) to rich (eutrophic). Human activities often enhance the rate of change, or at least modify it because of industrial and farming activity, road constructions, and building of waste treatment plants that all cause entrance of nutrients into the water cycle. This nutrient enrichment often results in a blooming of algae and other aquatic plants that lead to oxygen depletion and, therefore, to the reduction and even the destruction of the fish population. Consequently, native fish species disappear and are replaced by species that are more resistant to the new environmental conditions created by the supply of abnormal amounts of nu-

trients. Also, beaches and shorelines may be polluted by masses of rotten algae. In order to assess the eutrophication state of the Nador lagoon water, as for the Slimane-El Maleh lagoon of Tunisia (Hadj et al. 2008), the LCIA method adapted to a natural lagoon has been applied.

\section{The analytical methods andresults}

\section{The experimental procedure}

To study the seasonal evolution of the contents in major nutrients, surface waters were sampled during a winter and a summer campaign at different sites in the lagoon (Fig. 1), and were analysed for their $\mathrm{P}$ and $\mathrm{N}$ contents. To make the comparisons with the Slimane-El Maleh lagoon even more accurate, sampling was made here at places in the lagoon that were similar to those collected in the other lagoon: near the entrance of the lagoon, near the outlet of creeks, and near the water treatment plant, as well as in more preserved places. Physical parameters such as $\mathrm{pH}$, temperature, conductivity, salinity, and Eh were measured on site right after sample collection (Bloundi 2005; Mostarih et al. 2016).

The waters were filtered on site right after collection by pressure using $0.45-\mu \mathrm{m}$ filters and were stored in polypropylene bottles at $4^{\circ} \mathrm{C}$. The analyses were performed by atomic absorption spectrometry (Hitachi Z8200) for $\mathrm{NO}^{-}, \mathrm{NO}^{-}$, and $\mathrm{PO}^{3-}$ and colorimetry (Technicon) for $\mathrm{NH}^{4+} .2$

\section{The available data}

Concerning the organic-related contamination, the surface sediments show variable rates in total organic carbon and sulfur that are especially high in the centre of the lagoon at 7.5 and $1.8 \%$, respectively. The n-alkanes distribution reveals a zone of "marine" influence and a zone of "continental" influence in the lagoon, while pentacyclic tri-terpanes point towards a contamination by petroleum products in the entire 
193

194

195

196

197

198

199

200

201

202

203

204

205

206

207

208

209

210

211

212

213

$\mathrm{t} 1: 1$

$\mathrm{t} 1: 2$
$\mathrm{t} 1: 3$

$\mathrm{t} 1: 4$

$\mathrm{t} 1: 5$

t1:6

$\mathrm{t} 1: 7$

t1:8

t1:9

Q6 $\mathrm{t} 1: 10$

t1:11

$\mathrm{t} 1: 12$

$\mathrm{t} 1: 13$

t1:14 Winter

$\mathrm{t} 1: 15$

$\mathrm{t} 1: 16$

$\mathrm{t} 1: 17$

$\mathrm{t} 1: 18$

$\mathrm{t} 1: 19$

$\mathrm{t} 1: 20$

$\mathrm{t} 1: 21$

$\mathrm{t} 1: 22$

$\mathrm{t} 1: 23$ lagoon except in the centre. In turn, the organic petroleum byproducts and the wastewater effluents are especially high near the cities, whereas the littoral and central parts of the lagoon remain less polluted by these contaminations (Bloundi et al. 2008b).

\section{The eutrophication factors}

The determined $\mathrm{P}$ and $\mathrm{N}$ concentrations show that the main contributors to eutrophication are $\mathrm{N}$ compounds for the nine water samples during both the summer and winter sampling campaigns (Table 1; Fig. 2). In summer, the sample at the output of the wastewater plant of Bouaroug (location 4) yields the higher contents at $0.78 \mathrm{mg} / \mathrm{L}$ for the $\mathrm{N}$ compounds followed at $0.35 \mathrm{mg} / \mathrm{L}$ by that near the city of Beni Ensar at the northern end of the lagoon (location 1). These two contents are ten times higher than those of the winter sampling. The water sample of location 4 contains also two times more $\mathrm{P}$ compounds in summer than in winter. In summer, the wastewater treatment plant discharges directly into the lagoon part of the wastewater loaded with $\mathrm{N}$ and P. Indeed, during this season, the population triples and the undersized plant is unable to treat all of the wastewaters. The values of the $\mathrm{N}$ compounds at the sampling place next to the city of Beni Ensar (location 1) can be due to inputs of the oueds draining the local watershed. Conversely, the water samples of the barrier island (location 7) and next to the pass (location 8) yield two times more $\mathrm{N}$ compounds in winter than in summer. The samples of the locations 2, 6, and 8 yield very similar $\mathrm{P}$ contents for the summer and the winter, suggesting that the average $\mathrm{P}$ contents of the lagoon waters are close of those of these samples. The sample collected in the middle of the lagoon (location 9) is systematically the lowest for both the $\mathrm{N}$ and $\mathrm{P}$ contents, suggesting the lowest pollution probably due a better oxygenation by marine currents.

The relationship between the seasonal development cycle of the phytoplankton and the $\mathrm{N}$ and $\mathrm{P}$ nutritional cycles in the

Slimane-El Maleh lagoon where the $\mathrm{N}$ concentrations are more important than those of $\mathrm{P}$ in winter, the opposite occurring in summer (SETAC 2002), is not reproduced here: the $\mathrm{N}$ contents are always higher than the $\mathrm{P}$ ones in summer. No general law can be drawn for the winter data as the concentrations of the $\mathrm{N}$ compounds are either lower than those of the $\mathrm{P}$ compounds in the confined areas of $\mathrm{N}$ and $\mathrm{S}$ of the lagoon, or higher in the centre of the lagoon, near the barrier island, the treatment plant, and the irrigation channel (Table 1).
214 215 216 217 218 219 220 221 222 223 224 225 226 227 228 229 230 231 232 233 234 235 236

Table $1 \quad \mathrm{P}$ and $\mathrm{N}$ concentrations in $\mathrm{mg} / \mathrm{L}$ of waters of Nador lagoon in summer and winter times

\begin{tabular}{|c|c|c|c|c|c|c|c|c|c|c|}
\hline & $\begin{array}{l}\text { Sample ID } \\
\text { Location }\end{array}$ & $\begin{array}{l}1 \\
\text { Beni } \\
\text { Ensar } \\
\text { City }\end{array}$ & $\begin{array}{l}2 \\
\text { N Sidi } \\
\text { Youssef } \\
\text { Oued }\end{array}$ & $\begin{array}{l}3 \\
\text { Nador } \\
\text { City }\end{array}$ & $\begin{array}{l}4 \\
\text { Step } \\
\text { Bouaroug }\end{array}$ & $\begin{array}{l}5 \\
\text { Irrigation } \\
\text { Channel }\end{array}$ & $\begin{array}{l}6 \\
\text { Arekman } \\
\text { Village }\end{array}$ & $\begin{array}{l}7 \\
\text { Barrier } \\
\text { Island }\end{array}$ & $\begin{array}{l}8 \\
\text { Pass }\end{array}$ & $\begin{array}{l}9 \\
\text { Centre of } \\
\text { lagoon }\end{array}$ \\
\hline \multirow[t]{10}{*}{ Summer } & $\begin{array}{l}\mathrm{NH}_{4}^{+} \\
(\mathrm{mmol} / \mathrm{l})\end{array}$ & 0.001 & 0.001 & 0.001 & 0.048 & 0.001 & 0.001 & 0.001 & 0.001 & 0.001 \\
\hline & $\mathrm{NH}_{4}^{+}(\mathrm{mg} / \mathrm{l})$ & 0.018 & 0.018 & 0.018 & 0.864 & 0.018 & 0.018 & 0.018 & 0.018 & 0.018 \\
\hline & $\mathrm{N}(\mathrm{mg} / \mathrm{l})$ & 0.014 & 0.014 & 0.014 & 0.672 & 0.014 & 0.014 & 0.014 & 0.014 & 0.014 \\
\hline & $\begin{array}{l}\mathrm{NO}_{3}^{-} \\
(\mathrm{mmol} / \mathrm{l})\end{array}$ & 0.024 & 0.004 & 0.004 & 0.008 & 0.003 & 0.003 & 0.003 & 0.004 & 0.003 \\
\hline & $\mathrm{NO}_{3}^{-}(\mathrm{mg} / \mathrm{l})$ & 1.488 & 0.248 & 0.248 & 0.496 & 0.186 & 0.186 & 0.186 & 0.248 & 0.186 \\
\hline & $\mathrm{N}(\mathrm{mg} / \mathrm{l})$ & 0.335 & 0.056 & 0.056 & 0.116 & 0.042 & 0.042 & 0.042 & 0.056 & 0.042 \\
\hline & $\Sigma \mathrm{N}(\mathrm{mg} / \mathrm{l})$ & 0.349 & 0.070 & 0.07 & 0.788 & 0.056 & 0.056 & 0.056 & 0.070 & 0.056 \\
\hline & $\begin{array}{l}\mathrm{PO}_{4}{ }^{3-} \\
\quad(\mathrm{mmol} / \mathrm{l})\end{array}$ & 0.001 & 0.002 & 0.002 & 0.004 & 0.002 & 0.001 & 0.001 & 0.002 & 0.001 \\
\hline & $\mathrm{PO}_{4}{ }^{3-}(\mathrm{mg} / \mathrm{l})$ & 0.095 & 0.190 & 0.190 & 0.380 & 0.190 & 0.095 & 0.095 & 0.19 & 0.095 \\
\hline & $\mathrm{P} \mathrm{mg} / \mathrm{l}$ & 0.031 & 0.062 & 0.062 & 0.124 & 0.062 & 0.031 & 0.031 & 0.062 & 0.031 \\
\hline \multirow[t]{10}{*}{ Winter } & $\begin{array}{l}\mathrm{NH}_{4}^{+} \\
\quad(\mathrm{mmol} / \mathrm{l})\end{array}$ & 0.001 & 0.001 & 0.001 & 0.001 & 0.001 & 0.001 & 0.002 & 0.006 & 0.001 \\
\hline & $\mathrm{NH}_{4}^{+}(\mathrm{mg} / \mathrm{l})$ & 0.018 & 0.018 & 0.018 & 0.018 & 0.018 & 0.018 & 0.036 & 0.018 & 0.018 \\
\hline & $\mathrm{N}(\mathrm{mg} / \mathrm{l})$ & 0.014 & 0.014 & 0.014 & 0.014 & 0.014 & 0.014 & 0.028 & 0.084 & 0.014 \\
\hline & $\begin{array}{l}\mathrm{NO}_{3}^{-} \\
\quad(\mathrm{mmol} / \mathrm{l})\end{array}$ & 0.002 & 0.001 & 0.005 & 0.004 & 0.003 & 0.004 & 0.008 & 0.006 & 0.002 \\
\hline & $\mathrm{NO}_{3}^{-}(\mathrm{mg} / \mathrm{l})$ & 0.124 & 0.062 & 0.31 & 0.248 & 0.186 & 0.248 & 0.496 & 0.372 & 0.124 \\
\hline & $\mathrm{N}(\mathrm{mg} / \mathrm{l})$ & 0.028 & 0.014 & 0.070 & 0.060 & 0.042 & 0.056 & 0.011 & 0.084 & 0.028 \\
\hline & $\Sigma \mathrm{N}(\mathrm{mg} / \mathrm{l})$ & 0.042 & 0.028 & 0.084 & 0.074 & 0.056 & 0.070 & 0.039 & 0.168 & 0.042 \\
\hline & $\begin{array}{l}\mathrm{PO}_{4}{ }^{3-} \\
\quad(\mathrm{mmol} / \mathrm{l})\end{array}$ & 0.002 & 0.002 & 0.001 & 0.002 & 0.001 & 0.002 & 0.002 & 0.002 & 0.001 \\
\hline & $\mathrm{PO}_{4}^{3-}(\mathrm{mg} / \mathrm{l})$ & 0.190 & 0.190 & 0.095 & 0.190 & 0.095 & 0.190 & 0.190 & 0.190 & 0.095 \\
\hline & $\mathrm{P}(\mathrm{mg} / \mathrm{l})$ & 0.062 & 0.062 & 0.031 & 0.062 & 0.031 & 0.062 & 0.062 & 0.062 & 0.031 \\
\hline
\end{tabular}

The $\mathrm{NO}_{2}$ molecules were counted with the $\mathrm{NO}_{3}$ molecules. Compounds in $\mathrm{mmol} / \mathrm{l}$ were converted to $\mathrm{mg} / \mathrm{l}$, and then, this concentration in $\mathrm{mg} / \mathrm{l}$ was multiplied by the molar mass of the compound. Then, the percentage of nitrogen for nitrogen compounds and phosphorus for phosphorus compounds was calculated within the concentrations of the corresponding compounds 

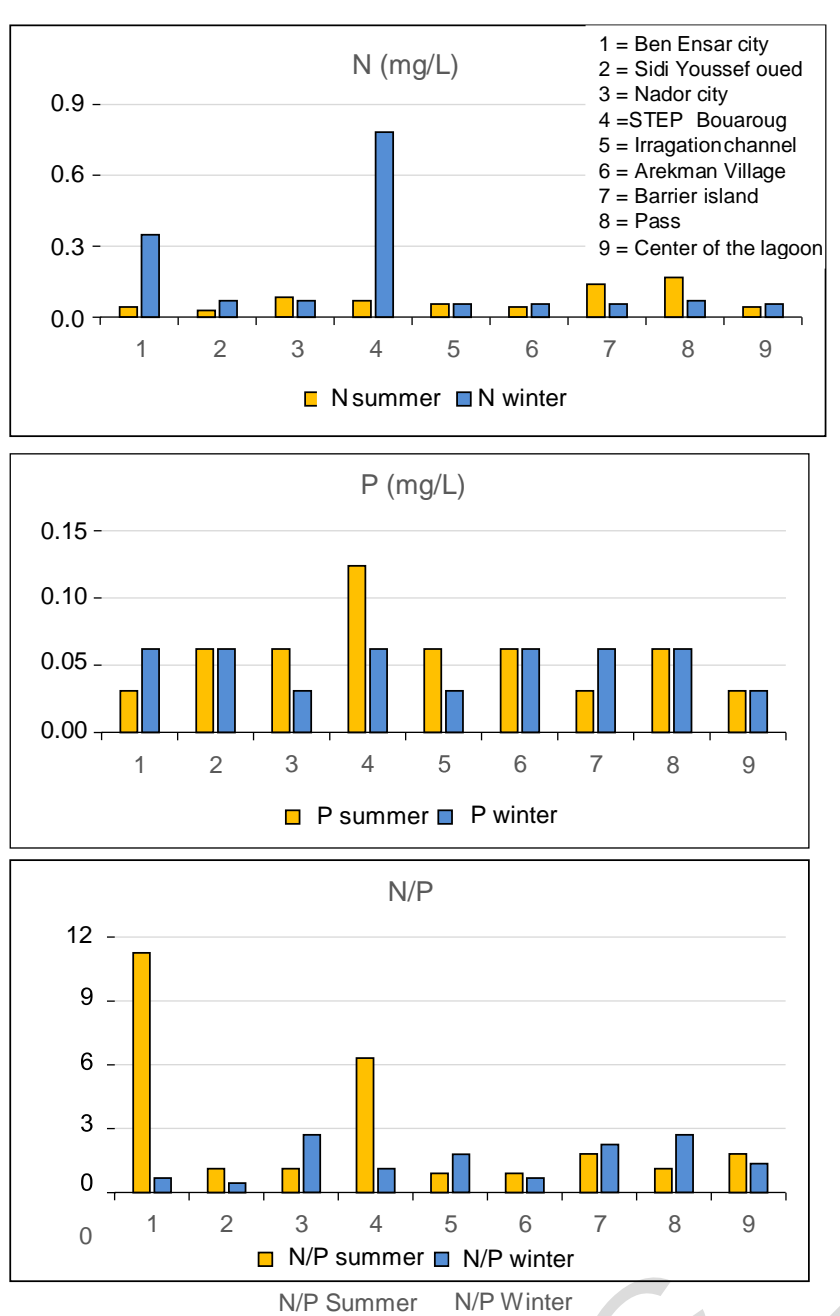

Fig. 2 Concentrations in $\mathrm{mg} / \mathrm{l}$ of the analysed nutrients and the related $\mathrm{N} / \mathrm{P}$ ratio into the waters of the Nador lagoon
Eutrophication is commonly visualized by the N/P ratio called the Redfield ratio. It describes the overall composition of $\mathrm{C}, \mathrm{N}$, and $\mathrm{P}$ at respective concentrations of 106:16:1 in phytoplankton (Finnveden and Potting 1999). In other words, 106 moles of $\mathrm{C}$ and 16 moles of $\mathrm{N}$ are consumed while 172 atoms of $\mathrm{O}$ are produced for 1 mole of used $\mathrm{P}$ in the photosynthesis. According to this ratio, 1 mole of $\mathrm{N}$ emitted produces 6.6 moles organic $\mathrm{C}$ in the biomass, whereas the corresponding amount is as much as 106 moles in the case of P. If algae growth is optimal in an aquatic environment, the N/P ratio is equal to 16 , while $\mathrm{P}$ is the limiting factor of the algae growth for an $\mathrm{N} / \mathrm{P}$ ratio above 16 and, alternatively, nitrogen is the limiting factor for an N/P ratio below 16. Here, the N/P ratio is systematically lower than 16 wherever the sampling site, which indicates that $\mathrm{N}$ is the systematic limiting factor and is the higher contributor to the eutrophication (Fig. 3). Especially, $\mathrm{NO}_{3}{ }^{-}$has a high rate in winter due to its leaching from catchment area and some releases from lagoon sediments. (Mostarih et al. 2016). The N/P ratio is higher in summer, in the confined area of the Beni-Ensar city and near the outlet of the wastewater plant of Bouaroug due to urban releases and $\mathrm{N}$ fertilizers used in the nearby agricultural plain, and also to storage of the waste mud from water treatment plant. The highest N/P values were obtained in winter for the sample collected at the pass with the open sea (location 8; Table 2).

In comparing the results obtained here with those of water samples collected at similar places in the Slimane-El Maleh lagoon in Tunisia, the N/P ratio is not systematically higher in the summer relative to the winter. However, even if this ratio is systematically below the reference value of 16 in the Nador lagoon and often in the Slimane-El Maleh lagoon, the high ratios in summer time are from near the wastewater treatment plants. In turn, the model suggested for the functioning of the Slimane-El Maleh lagoon (Hadj et al. 2008) is applicable here, the Nador lagoon appearing, however, to be less eutrophic than that of Slimane-El Maleh.

It also looks like that the load in organic matter and nutritive salts of the domestic wastewaters entering the Nador lagoon, the limited efficiency of the wastewater treatment by the plant, and probably the hydrodynamic functioning of the lagoon can generate seasonal periods of eutrophication that might be critical in some places. The water circulation in the lagoon favours the formation of a water mass rich in nutritive elements, as seems to be the case for the sample at the outlet to the sea (location 8) in wintertime, which might also be depleted in oxygen at the contact with the sediment. Conversely, the border currents seem to carry away the nutritive elements brought by the effluents, at least often. In summary, slow currents, weak salinity gradient, and low density facilitate somehow the diffusion of the $\mathrm{N}$ and $\mathrm{P}$ elements.

\section{Calculation of the aquatic eutrophication potential by the Life Cycle Impact Assessment method}

The LCIA method is routinely used in the industry for the study of environmental impacts during a production cyclefrom cradle to grave (ISO 14040, ISO 14044, 2006). It is based on the calculation of impact category indicators like acidification, global warming, and eutrophication, by using equivalent factors that indicate how much a substance contributes to a problem compared to a reference substance (Jensen et al., 1997; Guinée, 2001; Rebitzer et al., 2004). In an original application to natural environments, such as lagoons, Hadj et al. (2008) have shown that the lagoon waters are variably polluted by releases of water treatment plants, creeks, solid waste deposits, and agricultural activities. Seppälä et al.

(2004) evaluated the eutrophication impact caused by an anthropogenic system A within a region as:

$I_{E U}$ ठAР $1 / 4 \sum_{j^{1 / 41}}^{n} C_{j ; i}$ ठ $A \mathrm{P} \cdot E_{j}$ ठAP; 
Q8 t2:1 Table 2 Aquatic eutrophication potentials (AEP) of waters of Nador lagoon

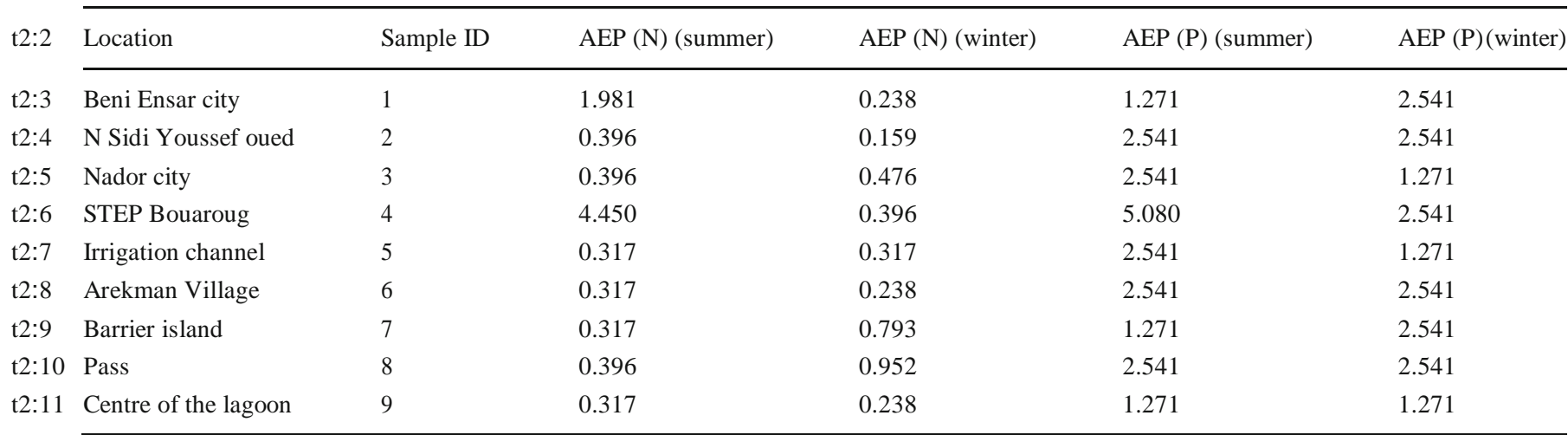

of the substance $j$ caused by the system $A$ that will reach a given water area $i$, and $E_{j}(A)$ is the emitted amount of substance $\mathrm{j}$ due to the system $A$. The characterization factor adapted from Seppälä et al. (2004) can then be expressed by transport and effect factors:

$C_{j ; i} \partial A \mathrm{P} 1 / 4 \eta_{j ; i} \partial A \mathrm{P} \cdot \mu_{j ; i} \partial A \mathrm{P} \cdot E q v_{j} ;$

where $\eta_{j, i}(A)$ is the transport factor for the substance $j$, also

indicating the portion of the emitted substance $j$ that will reach a given water area $i ; \mu_{j, i}(A)$ is the effect factor of the substance $j$, indicating the portion of the transported substance $j$ that causes an increased production of biomass in a given water area $I$; and $E q v_{j}$ is the equivalency factor of the substance $j$ that is usually expressed as kilogram $\mathrm{PO}_{4}{ }^{3-}$ equivalent per kilogram of emitted substance $j$.

Gallego et al. (2010) and Barba-Brioso et al. (2010) introduced transport factors into the calculation of aquatic eutrophication by the LCIA at a country scale, to evaluate if the impact factor does allow an exhaustive assessment. Here the LCIA is rather used to recognize variations of a limiting nutrient and of aquatic eutrophication potential that result from

inputs of variable concentrations of nutrients ( $\mathrm{N}$ and $\mathrm{P}$ ) due to anthropogenic activities around and in the lagoon. It has been adjusted here at the specific scale of the Nador lagoon. There is then no reason to include a transport factor or an effect factor into the calculation. Consequently, the characterization factor is equal to the equivalency factor (see Eq. (2)).

Concerning the eutrophication impact, the LCIA method uses the Redfield ratio for the characterization factors of contaminant emissions. The basic approach to characterize different emissions of pollutants or nutrients is:

$A E P 1 / 4 E P i \times \sum_{i} M i$

where AEP is the aquatic eutrophication potential, $M i$ the mass of the aquatic eutrophicating emission, $i$ the impact category aquatic eutrophication ( $\mathrm{kg} \mathrm{i}$ ), and $E P i$ the characterization factor of the emission $i$ based on the

Redfield ratio (Redfield et al. 1993). The specific aspect to address when applying the LCIA method to a lagoon is the examination of the algae proliferation. Algae growth requires favourable mineral species in the surrounding water, with $\mathrm{C}$ being the dominant chemical element, followed by $\mathrm{H}$ and $\mathrm{O}$.

Alternatively, $\mathrm{P}$ is the first element that is lacking in natural conditions, before $\mathrm{N}$ and $\mathrm{C}$. Therefore, $\mathrm{P}$ becomes normally

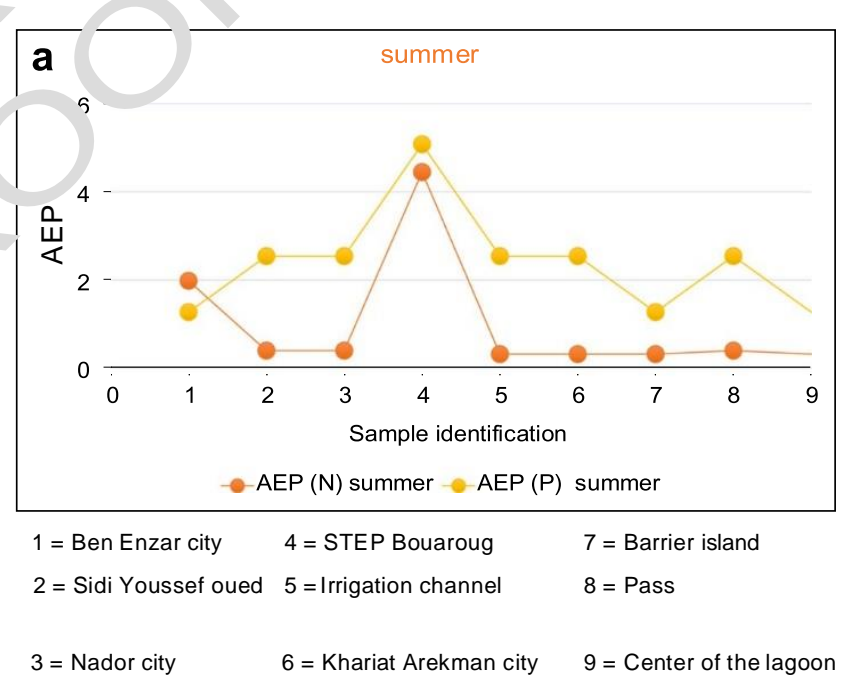

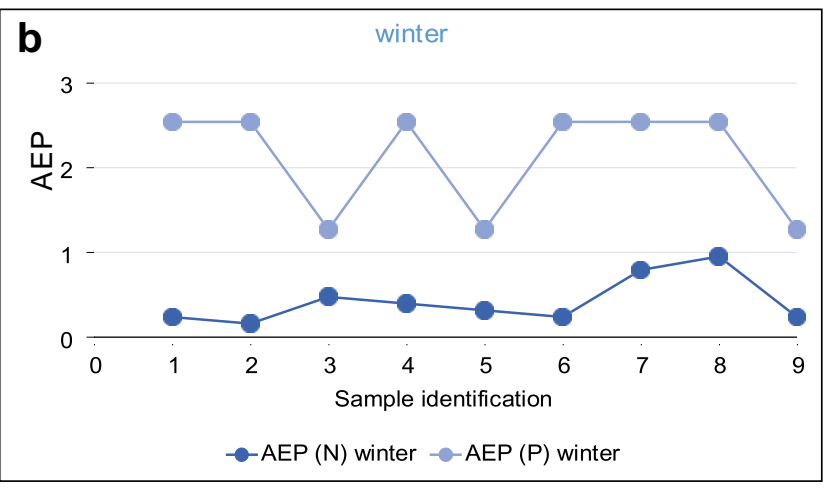

Fig. 3 a, b Comparison of AEP (N) vs. AEP (P) values for the waters of Nador lagoon. (1) Ben Ensar city. (2) Sidi Youssef oued. (3) Nador city. (4) STEP Bouaroug. (5) Irrigation channel. (6) Arekman village. (7) Barrier island. (8) Pass. (9) Centre of the lagoon 
the "limiting factor" as an abnormally high anthropogenic input of $\mathrm{P}$ in waters induces a lack of N. In this case, the cyanobacteria proliferate in fixing atmospheric $\mathrm{N}$ to compensate this lack of $\mathrm{N}$, which is recycled in the aquatic environment. On a limited scale of time and space, $\mathrm{N}$ may appear as the limiting factor and consequently it may hide the fact that $\mathrm{P}$ is the true limiting factor at a global scale (Barroin 2003). This is why the $\mathrm{P}$ and $\mathrm{N}$ compounds, which are the most important factors for limiting the growth rate of aquatic plants, are taken into account in the case of aquatic eutrophication (SETAC, 2002).

The aquatic eutrophication potential associated with $\mathrm{P}$ compounds (AEP (P)) has scores 2 to 16 times higher than $\operatorname{AEP}(\mathrm{N})$ in winter. In summer, the $\mathrm{AEP}(\mathrm{P})$ always dominates the AEP (N) but less significantly, the AEP (P) being 1 to 8 times higher than the AEP $(\mathrm{N})$ according to the determined data. This means that the supply of $\mathrm{P}$ compounds to the lagoon is greater than that of $\mathrm{N}$ compounds, which confirms the results of the Redfield ratio showing that $\mathrm{N}$ is the limiting factor of algal growth in the Nador lagoon (Fig. 3a, 3b). In the detail, a focus on the release of wastewater treatment plant of Bouaroug (location 4) shows an AEP (P) of 5, which is twice the average score of the AEP $(\mathrm{P})$ of the lagoon knowing that the lowest AEP value is that of the centre of the lagoon (location 9) with a score of 1.27. This last one is also found at the level of the barrier island (location 7) and the city of Beni Ensar (location 1).

In winter, no analysis outlines a high AEP $(\mathrm{P})$ compared to an average score of 2.5 , the lowest value being 1.27 in the centre of the lagoon (location 9). This score is obtained for the water sample collected at the exit of the irrigation canal (location 5) and near the city of Nador (location 3). No realistic explanation can be suggested as to the value of these three locations. The average AEP $(\mathrm{N})$ in summer being 0.3 , the results of three locations fall out: the wastewater treatment plant of Bouaroug (location 4) with a score of 4.4 and the city of Beni Ensar (location 1) with a score of 1.98. The first value relates to the discharge of urban water and the other to the local confined area. In winter, the $\operatorname{AEP}(\mathrm{N})$ scores are between 0.15 and 0.47 , with only two results outside: the barrier island (location 7) and the pass (location 8) with scores of 0.79 and 0.95 , respectively, that indicate a source of $\mathrm{N}$ compounds from marine waters or from re-suspension of the sediments of the barrier island.

\section{Conclusions}

Waters from Nador lagoon, as well as waters from Slimane-El Maleh lagoon in Tunisia, show the potential of using the Life Cycle Impact Assessment in the case of an ecosystem undergoing eutrophic pressures. In the case of the Nador lagoon ecosystem, the environmental trophic state examined by the nitrogen and phosphorus impact factors into the waters allows evaluation of their contribution to eutrophication. In contrast to previous studies of other lagoons, the role of seasonal variations in concentrations of the nitrogen and phosphorus compounds has not been demonstrated nor a clear predominance of nitrogen or phosphorus. However, there is clearly a direct relationship between releases of the Bouaroug wastewater plant and the nitrogen and phosphorous summer concentrations that are about 2 times higher than the average concentrations of the lagoon. There is also a direct relation in summer between nitrogen compounds and the confined area of the Beni Ensar city.

The assessment of the aquatic eutrophication potential of the waters of the Nador lagoon shows that AEP $(\mathrm{P})$ is higher than AEP (N), which confirms an eutrophication due to excessive phosphorus inputs. Several options for reducing the risk of eutrophication can be suggested: a systematic monitoring of the urban discharges with the construction of a wastewater plant for the population of the Beni Ensar city, phosphorus removal of the existing station or extension of its treatment capacity, and reduction of the diffuse leaching of the agricultural site, which all would reduce the exportation of $\mathrm{N}$ and $\mathrm{P}$ loads into the confined lagoon.

\section{Declaration}

Conflict of Interest The authors declare that they have no competing interests.

\section{References}

Barba-Brioso C, Quaranta G, Galàn E, Fernàndez-Caliani JC, Miras A (2010) the life cycle impact assessment applied to the Domingo Rubio tidal system by study of seasonal variations of the aquatic eutrophication potential. Sci Total Environ. https://doi.org/10.1016/ j.scitotenv.2010.08.002

Barroin G (2003) Santé et environnement : le cas des nitrates- phosphore, azote et prolifération des végétaux aquatiques. Le courrier de l'environnement, p 48. (in French)

Bloundi MK (2005) Etude géochimique de la lagune de Nador (Maroc oriental): Impact des facteurs anthropiques. Thèse Doctorat esSciences, Université Louis Pasteur de Strasbourg (France) et Université Mohamed V - Agdal de Rabat (Maroc), p 238. (in French)

Bloundi MK, Duplay J, Quaranta G (2008a) Heavy metal contamination of coastal lagoon sediments by anthropogenic activities: The case of Nador (East Morocco). Environ Geol 56:833-843

Bloundi MK, Faure P, Duplay J (2008b) Organic contamination identification in sediments from a Mediterranean coastal ecosystem: The case of the Nador lagoon (eastern Morocco). Compt Rendus Geosci 340:840-849

Boyauzan A, Irzi Z (2015) Impacts of man-made structures on sediment fluxes and water circulation around the barrier island of the Nador lagoon (north-east of Morocco, Oriental region). J Mediterr Geogr 125:85-94 
Conley DJ, Markager S, Andersen J, Ellerman T, Svenden LM (2002) Coastal Eutrophication and the Danish National Aquatic Monitoring and Assessment Program. Estuaries 25(4b):848-861

Duplay J, Semhi K, Bloundi MK, Khediri S, Ben AR, Darragi F (2012) Geochemical background and contamination level assessment in Tunisian and Moroccan Mediterranean costal logoon sediments. Environ Earth Sci 67:1201-1214

Elalami M, Mahjoubi R, Damnati B, Kamel S, Icole M, aeib M. (1998) Sédimentologie et géochimie organique des sédiments superficiels de la lagune de Nador (Maroc nord-oriental). J Afr Earth Sci 26(2): 249-259 (in French)

Finnveden G, Potting J (1999) Eutrophication as an impact category. Int J LCA 4(6):311-314

Guelorget Oand Perthuisot JP(1983)Ledomaineparalique: Expressions géologiques, biologiques etéconomiques du confinement. Travaux du Laboratoire de Géologie, Ecole Normale Supérieure, Paris, série 156, ${ }^{\circ} 16, \mathrm{p} 136$ (in French).

Hadj AR, Quaranta G, Gueddari F, Million D, Clauer N (2008) The life cycle impact assessment applied to a coastal lagoon: the case of the Slimane lagoon (Tunisia) by the study of seasonal variations of the Aquatic Eutrophication Potential. Environ Geol 54:1103-1110

Howarth RW, Sharpley A, Walker D (2002) Sources of Nutrient Pollution to Coastal Waters in the United States: Implications for Achieving Coastal Water Quality Goals. Estuaries 25(4b):656-676

Huijbregts MAJ, Seppälä J (2000) Towards Region-Specific, European Fate Factors for Airborne Nitrogen Compounds Causing Aquatic Eutrophication. Int J LCA 5(2):65-67

Inani I (1995) Dynamique Sédimentaire et Etat de Pollution dans la lagune de Nador. Thèse de 3eme Cycle, Université Mohammed V, Rabat p.186 (in French).

International Organization for Standardization ISO 14040, ISO 14044 (2006) Environmental Management - Life cycle assessment Principle and framework. AFNOR, Paris

Irzi Z (2002) Les environnements du littoral méditerranéen oriental du Maroc compris entre l'Oued Kiss et le Cap des Trois Fourches,

Dynamique sédimentaire et évolution écologique des foraminifères benthiques de la lagune de Nador, Thèse de Doctorat ès Sciences. Université Mohamed I, Oujda, $279 \mathrm{p}$

Lefebvre A, Guelorget O, Perthuisot JP, Dafir JE (1997) Evolution biogéologique de la lagune de Nador (Maroc) au cours de la période 1982-1993. Oceanol Acta 20:371-385
Mabrouk A (1988) Etude bactériologique de la lagune de Nador. Thèse Doctorat Vétérinaire, Université Hassan II, Rabat, 123 p + annexes (in French).

MahjoubiR(2001) Nature et origine du flux de matière particulaire et son enregistrement dans un milieu paralique microtidal : cas de la lagune de Nador (Maroc Nord Oriental), Thèse de Doctorat ès Sciences, Université Moulay Ismail, Meknes, p 231 (in French).

Mahjoubi R, Kamel S, El Moumni B, Noack Y, Parron C (2003) Nature, origine et répartition de la phase argileuse de la lagune de Nador (Maroc Nord Oriental). Geol Belg 6(1-2):31-42

Mostarih M, El Madani F, Yahya HSA, El Hachemi O, Abdellaoui S, Chafi A (2016) Evaluation physico-chimique de la qualité de l'eau de la lagune de Nador- $\mathrm{N}$ du Maroc Oriental- après l'ouverture de la passe. J Mater Environ Sci 7:4795-4809

Parinet B, Lhote A, Legube B (2004) Principal component analysis: an appropriate tool for water quality evaluation and management-application toa tropical lake system. EcolModel178(3-4):295-311117

Redfield AC, Ketchum ${ }^{-H}$ and 'ichards FA (1963) The influence of organisms on the co, nosit ${ }^{\prime}$ n of sea water. The sea 2, (M.N. Hill, Editor), Wile Inte"scit. e, New York, 26-77.

Redfield AC, Ke, ' ' An $^{\mathrm{r}}$. and Richards FA (1993) The influence of organis as on $\mathrm{t}$. - omposition of sea water. Proceedings of the 2nd ante ational Water Pollution Conference; Tokyo, Japan. P amon, x xford, 215-243.

Sep älä J, Inuutila S, Silvo K (2004) Eutrophication of Aquatic Ecosy iems. A new method for calculating the potential contributluns of Nitrogen and Phosphorus. Int J LCA 9(2):90-100 Smil V (2000) Phosphorus in the Environment: Natural Flows and Human Interferences. Annu Rev Energy Environ 25:53-88

Smith VH (2003) Eutrophication of Freshwater and Coastal Marine Ecosystem. A Global Problem. Environ Sci Pollut Res 10:126-139

Society of Environmental Toxicology and Chemistry (2002) Life-Cycle Impact Assessment: Striving towards best practice. SETAC Press, $p$ 250.

Tesson M and Gensous B (1981) Quelques caractères de la géochimie d'une lagune microtidal : la Sebkha Bou-Areg (Maroc). 106ème Congrès des Sociétés Savantes, Perpignan, Faculté des Sciences, Fasc. III, 183-194 (in French). 
